\title{
INTERNATIONAL JOURNAL OF EPILEPSY
}

\section{Hanneke de Boer, RIP}

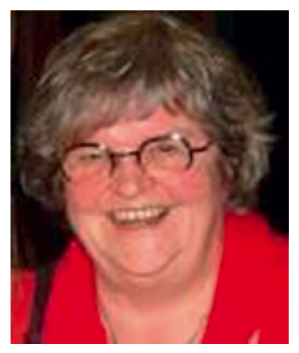

$(1946-2015)$

It was very sad to learn about the passing away of Hanneke de Boer on 12th October, 2015.

I first met Hanneke in 1989 (she was then the Secretary General of the IBE), during the 18th International Epilepsy Congress that we proudly hosted in New Delhi. Since then our association and friendship grew and we continued to work together on many important aspects of the global epilepsy movement. It was during her tenure as the IBE President in 1997 that her relentless crusade culminated in the successful launch of the ILAE/IBE/WHO Global Campaign Against Epilepsy. She nominating me as the Resource Person from Asia in the GCAE that provided me another opportunity to know her better from both the professional and personal point of view.

Having begun her professional life as a vocational consultant at the Stichting Epilepsie Instellingen Nederland (SEIN) in Heemstede, the Netherlands in 1965, Hanneke got actively involved with IBE about two decades later and became Editor of IE News and a member of the Executive Committee. She rose to become Secretary General of the IBE in 1989 and served as its President from 1993 to 1997.

The long list of awards that Hanneke was decorated with includes the IBE/ILAE Ambassador for Epilepsy award in 1987, the Social Accomplishment award in 1995 and the Lifetime Achievement Award in 2009. Her contributions didn't go unnoticed even in her own country, the Netherlands. As per the information provided by the IBE, she received the Award of the Christian Society for the Care of People with Epilepsy in 1982, the Spike and Wave award of the Dutch Branch of ILAE in 1997, and was inducted as an Officer of the Orange Order of Nassau by the Royal Dutch House (the last one being one of the highest awards presented in the Netherlands and is rarely conferred).

Hanneke always worked with a tremendous zeal and was a source of inspiration to many of us globally. She was truly one of the greatest and longest serving advocates for people with epilepsy. Her seminal contributions towards the global epilepsy movement will always be recognized internationally and remembered forever.

In her passing away after a prolonged illness, we in India have lost a close friend. The void left by her demise will be very difficult to fill in the years to come.

Since she achieved so much in her lifetime, I am sure that she left for her heavenly abode with nothing more to desire while breathing her last. She achieved 'Moksha' in the true sense!

Dear Hanneke, RIP.

SATISH JAIN, MD; DM; FRCP

President-Indian Epilepsy Association 